\title{
Bullying Intervention in Adolescence: The Intersection of Legislation, Policies, and Behavioral Change
}

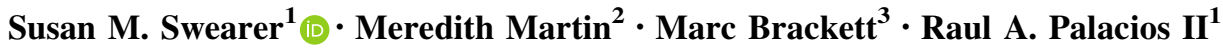

Received: 31 May 2016/Accepted: 18 July 2016/Published online: 4 August 2016

(C) Springer International Publishing 2016

\begin{abstract}
This article reviews current research on bullying during adolescence. The complexity of bullying behaviors during the adolescent time period are discussed and a review of the developmental literature on adolescence provides suggestions for why current bullying prevention and intervention programs are less effective for this age group. Current anti-bullying policies and legislation are reviewed under a framework of adolescent brain development and the development of consequential thinking. Suggestions for implementing social-emotional learning programming during the adolescent period are provided and a novel approach using social media is presented. In order to effectively combat bullying during this developmental period, programming must focus of positive behavioral development and restorative practices.
\end{abstract}

Keywords Adolescence $\cdot$ Bullying $\cdot$ Social-emotional learning

\section{Introduction}

Schools have been inundated over the past 20 years with bullying prevention and intervention programs (Ferguson et al. 2007; Ryan and Smith 2009; Ttofi and Farrington 2009, 2011; Polanin et al. 2012). There are literally

Susan M. Swearer

sswearer@unl.edu

1 Bullying Research Network, University of Nebraska Lincoln, 40 Teachers College Hall, Lincoln, NE 68588-0345, USA

2 University of Rochester, Rochester, NY, USA

3 Yale University, New Haven, CT, USA hundreds of bullying- and aggression-prevention programs being used in schools worldwide (Leff et al. 2004). However, educators have a monumental task of selecting which bullying prevention program(s) will have the best chance of successfully reducing bullying in their respective schools (Ryan and Smith 2009). Traditionally, schoolbased anti-bullying efforts have involved universal programs administered to the entire school population, typically with the goal of increasing awareness about bullying and decreasing bullying behaviors among students (Swearer et al. 2010). Although hundreds of school antibullying programs have been developed and implemented, it is unclear whether these programs are successful in reducing bullying (Ferguson et al. 2007). More alarming is that some anti-bullying programs have been shown to decrease bullying by only twenty-three percent (Ttofi and Farrington 2011) and research has still not identified all of the critical components of effective anti-bullying programs (Hymel et al. 2015). Adding to this complexity is the fact that few studies have examined developmental patterns in the prevalence of bullying beyond early adolescence (Pepler et al. 2006).

While prevalence rates of bullying vary across studies and populations studied, approximately $22 \%$ of students ages 12-18 reported being bullied at school during the school year (Robers et al. 2015). Of those students, approximately $33 \%$ indicated they were bullied at least once or twice per month during the school year, and approximately $27 \%$ of students reported that they were cyber-bullied at least once or twice per month. Research has also examined the prevalence of cyber-harassment among college students and found that $33.6 \%$ of student had experience cyber-harassment in college and $28.4 \%$ had experienced in-person harassment while in high school (Beran et al. 2012). While it is difficult to draw conclusions 
across the sometimes conflicting research on bullying and harassment in adolescence, it appears that bullying and harassment affect approximate one in four adolescents.

Bullying and harassment are often used interchangeable, and in fact, some states call their anti-bullying legislation, HIB laws (harassment, intimidation, and bullying). While the words, "bullying," "harassment," "intimidation," and "drama" have all been used to describe mean and cruel behavior in adolescence, most researchers and educators agree that these behaviors are detrimental to the physical and mental health of those involved. Bullying and harassment can take many forms, including direct physical harm, verbal taunts and threat, exclusion, humiliation, rumorspreading, and electronic harassment using texts, e-mails, or online platforms (Hymel and Swearer 2015). Additionally, there is evidence to suggest that bullying and harassment negatively impact both children and adolescents in terms of their academic functioning, physical health and neurobiology, social relationships, self-perceptions, and their mental health (McDougall and Vaillancourt 2015). Despite the documented increase in anti-bullying legislation, anti-bullying programming, and awareness about the negative outcomes of involvement in bullying and harassment, the impact of bullying- and harassmentprevention programming appears to have minimal effects among high school and college students.

\section{Issues in Adolescent Development: Why Anti-Bullying Programs Are Not Working}

Understanding why anti-bullying programs are less effective for adolescents requires an analysis of adolescent development. A recent meta-analysis conducted by Yeager et al. (2015) investigating the efficacy of 19 anti-bullying intervention programs among mixed-ages found that current anti-bullying intervention programs for grades eight and above may not be as effective as previously purported. In their meta-analysis, the authors proposed three main considerations for the ineffectiveness of anti-bullying intervention programs at the secondary level: (1) Changes in the manifestation of problematic behavior, (2) Changes in underlying causes of the problematic behavior, and (3) Changes in the efficacy of domain-general behaviorchange techniques.

First, changes in the manifestation of problematic behavior between primary and secondary education students have made the development of age-appropriate antibullying programs difficult (Yeager et al. 2015). Prior research on peer bullying has focused primarily upon understanding the characteristics and comorbidities associated with physical forms of bullying (i.e., hitting, pushing, fighting) (Leff et al. 2004). However, Yeager et al.
(2015) argued that this may not be the best indicator of bullying among adolescents as direct forms of observable forms of aggression/bullying (e.g., hitting, insulting) become less prevalent as individuals age and more indirect forms of aggression/bullying (e.g., rumors, exclusion) become more prevalent.

Second, changes in the underlying causes of the problematic behavior across elementary, middle, and high school students may make it more difficult to identify the root causes of bullying behavior (Yeager et al. 2015). In the past, bullying behaviors displayed by youth were typically explained by a deficit in social-emotional awareness and a lack of empathetic behavior. Instead, Yeager et al. (2015) suggest that the changes in the underlying causes may be attributed to an adolescent's motivation to demonstrate social status due to biological and cognitive changes occurring during this developmental stage, an adolescent's concern for social conformity, and the ease of access to technology. With increased emphasis on autonomy, social conformity, and increased access technology, electronic bullying and harassment are more accessible.

Finally, Yeager et al. (2015) state that changes in the efficacy of domain-general behavior-change techniques may also be contributing to the ineffectiveness of antibullying programs at the secondary level. Although intervention programs may find success for elementary and middle school students, this does not necessarily translate to successful outcomes for adolescents. There are considerable developmental differences between students in primary school setting and students in secondary school settings. Among these developmental differences in adolescence can be the need for autonomy, an increase in assigned unsupervised time, the development of sexual relationships, greater exposure to drugs and alcohol, an increase in participation in various social media platforms, increased involvement in high-stakes activities, and the transition from high school to the workplace.

Even though adolescents have more autonomy than children, they may lack agency and focus in their lives and are regularly reminded of their limited economic or political power when presented with culturally pervasive messages that distinguish adults from children (Milner 2004). It is possible that adult-delivered, explicit rules against certain social behaviors, as well as direct instruction in the classrooms, threatens the adolescent's autonomy (Yeager et al. 2015). Autonomy-supportive contexts involve acknowledgment of the adolescent's feeling, taking the adolescent's perspective, providing rationales, allowing choice, and minimizing pressure (Roth et al. 2011). In their study, Roth et al. (2011) found that there was a reduction in self-reported bullying cases when teachers' attempted to take students' perspectives in relation to pro-social and anti-social behaviors in class. 
Another issue related to the autonomy of adolescents is the amount of unsupervised time students in secondary schools experience compared to students in elementary school. Typically, elementary school students are being supervised closely by teachers, paraeducators, administrators, and parent volunteers. Being within a closely supervised area generally decreases the opportunity for bullying behaviors to occur. However, as students transition to middle school and high schools, there is an exponential increase in freedom and autonomy. It is during this time that students have less supervision and might engage in risk-taking behaviors such as experimenting with drugs and alcohol. Recent research found that most high school students were not involved in bullying nor using drugs and alcohol, For example, Radliff et al. (2012) found that substance abuse and bullying status were correlated. They also found that youth who perpetrated bullying were more likely to report substance use and youth who both perpetrated bullying and who were bullied reported the highest level of substance use.

Changes in sexual maturity could also be a contributing factor to the ineffectiveness of anti-bully programs during adolescence. Pepler et al. (2006) conducted a study comparing sex differences in the prevalence of bullying, sexual harassment, and dating aggression, as well as comparing adolescents who did and did not report bullying on reports of perpetrating sexual harassment and dating aggression. Findings indicated that bullying others was highest around the transitional incoming year into high school with bullying being reported less frequently by the end of high school. Research suggests that weaker effects will occur on the overall prevalence of bullying or victimization as students age since the extant interventions are more successful at reducing direct, observable forms of aggression than more indirect, unobservable forms, or sexuality-related victimization (Yeager et al. 2015).

Additionally, sexual orientation and gender identity are also important developmental issues that intensify in adolescence. Few, if any, anti-bullying programs for adolescents address these important sexual and gender identity issues. Swearer et al. (2008) reported that the number of gay, lesbian, bisexual, and transgendered (GLBT) youth in the United States varies across studies, likely due to differences in methodologies and the way questions about sexual orientation are posed (Swearer et al. 2008). Unfortunately, many secondary schools in the U.S. have historically been heterosexist and homophobic institutions (Chesir-Teran 2003; Chesir-Teran and Hughes 2009; Espelage et al. 2008; Graff and Stufft 2011; Poteat 2008; Poteat et al. 2009; Rivers and Noret 2008; Swearer et al. 2008; Aragon et al. 2014). While this varies regionally and by districts, schools have been mandated to provide antibully programming that supports GLBT youth (Ali 2010).
This underscores the importance of effectively addressing bullying/victimization among adolescents, as lesbian, gay, bisexual, transgender, and questioning (LGBTQ) youth are disproportionately more likely to experience victimization (Aragon et al. 2014; Kull et al. 2015).

Social media also plays a role in an adolescent's strive for popularity and status since technology enables the prolific spread of information and allows adolescents to keep up with ever-changing social dynamics (Boyd 2014). In addition, various components of social media, and social networking sites in particular, function with a level of user anonymity (Keipi and Oksanen 2014). Because social media makes it easy to share information broadly, people can also easily spread hurtful gossip in an effort to assert status, get attention, or relieve boredom (Boyd 2014; Kull et al. 2015).

Finally, as students enter high school, they may carry the burden of high stakes decision making, which may impact their future educational and career goals. Students' involvement in high-stakes activities such as advanced placement (AP) courses, competitive high school sports, the SAT and ACT, and other extra-curricular activities that may determine academic scholarships to post-secondary education, places these students in a highly competitive atmosphere where bullying and harassment may be the outcome of this level of competition. Many high school students are also driving and entering the workforce for the first time in their lives. Their new found mobility and earning potential provides them with the possibility to engage in new opportunities not granted to elementary or middle school students. Given these development considerations, it is not sufficient to "age up" existing anti-bullying programs to meet the needs across all age groups (Yeager et al. 2015). There is a need to develop anti-bullying and anti-harassment programs that address developmental issues in adolescence.

\section{Policies, Legislation, and the Adolescent Brain}

\section{The Relationship Between State Legislative Mandates and School Policies}

The past two decades have seen a dramatic increase in public demand for anti-bullying legislation. Although there are currently no federal regulations against bullying in the U.S., as of March 2016, all fifty states have enacted laws requiring school districts have policies that address bullying. These laws vary widely in their scope and detail, but most include basic provisions for reporting and investigating cases of bullying, disciplinary action, and the training and responsibility of staff members (Cornell and Limber 2015; U.S. Department of Education 2011). In 
response to growing problems with cyberbullying, 48 states have expanded anti-bullying laws to include misbehavior off campus and online if it contributes to a hostile school environment (US Department of Education 2011; www. cyberbullying.org). Twenty-three of these states' laws refer specifically to "cyberbullying."

Anti-bullying laws are designed to improve school safety by mandating that schools develop policies to prohibit, respond to, and reduce the incidence of bullying (Dresler-Hawke and Whitehead 2009). To help districts adhere to these laws, 41 states have developed model bullying policies, providing guidelines for implementing anti-bullying initiatives and meeting state mandates (www. stopbullying.gov). There is limited research examining the efficacy of this legislation. However, an investigation by the U.S. Department of Education (2011) suggests that school districts in states with more expansive anti-bullying laws also tend to have more comprehensive and expansive policies. There is also some initial evidence that improving legislation can be beneficial in reducing bullying. Students in states with anti-bullying legislation meeting more of the standard guidelines proposed by the Department of Education were less likely to report bullying in school (Hatzenbuehler et al. 2015).

Despite these advances, a number of challenges face school districts attempting to meet state requirements. Anti-bullying laws rarely come with funding to support the development and implementation of school policy. Moreover, although some states provide model policies and implementation plans, many still offer no clear guidelines for school officials in how to meet state mandates (Weaver et al. 2013). There is currently no agreed-upon legislative definition of bullying across states. Adding to the potential for confusion, what constitutes bullying is often ambiguously worded, overly broad, and conflated with other legal definitions (i.e., harassment) (Gladden et al. 2014; Sacco et al. 2012; Swearer et al. 2009; U.S. Department of Education 2011).

The conflation of the terms harassment and bullying, in particular, impacts schools' ability to clearly and effectively address bullying. Cascardi et al. (2014) reported 22 states using the terms harassment and bullying synonymously in legislation and policy. Harassment has a long legal history as a term denoting threatening or abusive conduct against protected classes of individuals (e.g., based on gender, race, disability) (Cornell and Limber 2015). Laws that define prohibited behaviors in terms of harassment may be leaving victims who do not fall into one of the protected classes unprotected. At the same time, violation of federal civil rights laws take precedent over state- or district-level anti-bullying legislation. Confusing definitions may contribute to school officials' failure to meet their legal obligations in addressing harassment when bullying targets a member of a protected class (Dear Colleague Letters issued by the U.S. Department of Education 2010, 2013, 2014; Rose et al. 2012).

State's legal definitions of bullying also commonly differ from accepted scholarly definitions, which specify bullying as involving harmful behavior that is (a) intentional, (b) repeated, and (c) involving a power-imbalance (Gladden et al. 2014; Olweus 2013; Swearer et al. 2009). In contrast, legal policies often adopt a broader definition, equating bullying with peer conflict, threats, and aggression (Gladden et al. 2014). This may be due, in part, to the difficulty of assessing power imbalance. Adults and even adolescents themselves may not be attuned to the subtleties of perceived differences in power between peers (Cornell and Huang 2014; Olweus 2013). Nonetheless, this is a defining feature of bullying that distinguished it from other forms of peer aggression, and extensive research demonstrates that what is required to successfully address and prevent bullying is unique (Cascardi et al. 2014; Rodkin et al., 2015; Swearer et al. 2009). Policies and procedures that to not attend to the unique nature of bullying behavior run the risk of being ineffective, or even iatrogenic (Ttofi and Farrington 2011).

\section{Harsh Consequences and Zero Tolerance}

Ambiguity in legislative proscriptions extend to the consequences of bullying. Although the majority of states require or encourage disciplinary action for students who bully, the nature of these actions vary widely (Sacco et al. 2012). Most commonly, discipline takes the form of suspension or expulsion (Swearer et al. 2009; Cornell and Limber 2015). This is exemplified in the preponderance of Zero Tolerance policies adopted by schools in the wake of The Gun Free Schools Act of 1994 (Pub L No. 103-882, $\$ 14601)$. Originally designed to reduce severe school violence, school districts quickly expanded the scope of zero tolerance policies to encompass even relatively minor infractions such as fighting, disruptive behavior, truancy, and verbal disrespect (American Psychological Association 2008). This has empowered teachers and school officials to automatically expel or suspend adolescents, even for what amounts to obnoxious but relatively "normal" adolescent behavior. Today, bringing a weapon to school accounts for less than $2 \%$ of student suspensions and expulsions (Council on School Health 2013).

The regular adoption of zero tolerance policies to address bullying and related misbehavior persists despite the overwhelming evidence that this approach does not reduce bullying behavior and may even have significant costs in term of greater school disengagement and involvement in the juvenile justice system (Borgwald and Theixos 2013; Merrell et al. 2008; Sacks and Salem 2009; Skiba and Knesting 
2001). Clearly the emphasis is on punitive action as opposed to rehabilitation or school-wide climate change. In sharp contrast to the widespread use of zero tolerance policies, only one third of state anti-bullying laws advise providing counseling or other support service (Alley and Limber 2009; Sacco et al. 2012). This is in the face of clear evidence for deleterious mental health and adjustment consequences associated with bullying, for perpetrators as well as victims (Gina and Pozzoli 2009; Glew et al. 2008; Holt et al. 2015; McDougall and Vaillancourt 2015; Morgan et al. 2014; Swearer et al. 2009). Overly punitive responses to bullying can also have negative consequences for the school climate as a whole (Limber 2010). For example, schools applying more suspensions and expulsions have lower academic achievement school-wide, even after controlling for socioeconomic differences (American Psychological Association 2008; American Psychological Association Zero Tolerance Task Force 2006).

Schools' adoption of zero tolerance policies in regards to bullying may be exacerbated by liability fears. Although the tendency to settle out of court makes it difficult to precisely determine the frequency of litigation against schools related to bullying, there does appear to be a fairly dramatic increase in these cases over the past decade (Cornell and Limber 2015; Holben and Zirkel 2014). Several high profile cases, including Davis v. Monroe County Board of Education in (1999) and Scruggs v. Meriden Board of Education in 2006, have adjudicated against school districts on the ground that they evidenced "deliberate indifference" towards the plight of the victimized plaintiffs. Both of these cases involved violations of federal Title IX protections against sexual harassment. However, the trend may be moving towards greater liability for schools failing to protect students from peer bullying. In 2007, the New Jersey Supreme Court ruled in support of a student subjected to bullying based on his perceived sexual orientation, citing that "students in the classroom are entitled to no less protection than adults in the workplace" (LW v. Toms River Regional School Board of Education). The combination of fears for litigation, confusion regarding state laws about bullying, and the seeming ease of simply removing a troublesome student from the classroom sets up zero tolerance as a relatively "easy" option for addressing bullying behavior, regardless of its actual efficacy or cost to the students involved. The tendency to rely on suspensions as appropriate sanctions for misbehavior may also disrupt schools' ability to implement more comprehensive anti-bullying preventions (Hall and Chapman 2016).

\section{Bullying and the Adolescent Brain}

Unfortunately, laws and policy regarding bullying behavior is often formed without careful attention to developmental considerations during adolescence (Steinberg 2013). We now know that adolescents' brains continue to develop into their early 20's (Nelson et al. 2003; Steinberg 2008). The relative immaturity of the adolescent brain results in cognitive, emotional, and psychological biases that place them at particular risk for risky and delinquent behaviors, even in the face of clear negative consequences. Middle adolescence is characterized by a combination of heightened reward sensitivity and sensation-seeking, attunement to the peer group, and underdeveloped impulse control (Steinberg 2008; Steinberg et al. 2009; Luna et al. 2004). During this time, the limbic system (emotion) of the brain outpaces the development of the prefrontal cortex (cognitive control), resulting in an imbalance that favors impulsive and emotionally-driven decision making, particularly within emotionally charged situations (Cohen and Casey 2014; Mills et al. 2014; Somerville and Casey 2010). Given how emotionally provocative bullying can be, adolescents involved as perpetrators, victims, or bystanders may all be prone to acting impulsively, even when they know better.

In addition to this emotion-control imbalance, adolescents are highly attuned to the social group. Extensive research now supports later adolescence as the peak of social sensitivity and peer influence (Blakemore and Mills 2014; Crone and Dahl 2012; Somerville 2013). This is supported by fMRI research that demonstrates adolescents' greater activity in the reward-centers of the brain in response to the presence and positive social feedback of peers, relative to both children and adults (Jones et al. 2014; Smith et al. 2015; Steinberg 2010). Moreover, just the presence of peers leads adolescents to behave more impulsively and take greater risks (Gardner and Steinberg 2005; Steinberg 2010). Given that bullying occurs in the presence of bystanders more than $80 \%$ of the time (O'Connell et al. 1999; Polanin et al. 2012), peers likely play an important role in escalating the frequency and intensity of bullying behavior.

These unique features of the adolescent brain also highlight another aspect to bullying that has gone largely ignored by anti-bullying legislation and policy. Adolescents' unique sensitivity toward social rewards makes peer admiration and approval a particularly desirable goal. The developmental literature recognizes bullying behavior as being both goal-directed and associated with social benefits that can serve to sustain the behavior despite costs (e.g., Ellis et al. 2015; Hawley et al. 2011; Rodkin et al. 2015; Salmivalli 2010; Volk et al. 2014). For example, instances of bullying are commonly rewarded with immediate boosts to popularity, status, and self-esteem for perpetrators (Ellis et al. 2015; Reijntjes et al. 2013). The pull towards social rewards may be so salient that adolescents struggle to control their risk-taking behavior even when they are aware of the likelihood of negative consequences (Gardner and 
Steinberg 2005; Smith et al. 2014). This sensitivity, combined with tendencies to downplay future consequences in lieu of immediate rewards, suggests adolescents will be especially resistance to attempts to impose sanctions on status-relevant behaviors. In fact, high-status bullies, whose strategies have been most "successful" in eliciting social rewards, appear to be the most resistant to efforts to reduce bullying behavior (Garandeau et al. 2014).

Together, these findings suggest that current legislation and policy regarding bullying may be missing the mark. Overly harsh and punitive approaches focus on increasing the costs of bullying without equivalent attention to the potential rewards that may be sustaining these strategies (Ellis et al. 2015). Certain consequences, including out of school suspensions, may even increase the social or reputational benefits of misbehavior in the short-term in the form of positive feedback from peers. Considered in light of the evidence for adolescents' immature brain functioning, hardline policies mandating suspensions or expulsions seem especially harsh. The rationale for zero tolerance is based on the idea that harsh consequences will deter both a perpetrators' misbehavior and other students' misbehavior by making adolescents think twice about the costs (Cornell and Limber 2015). Unfortunately, adolescents rarely think twice. Their ability to consider the long-term consequences of their actions and to control their impulses are impaired (Luna et al. 2004; Steinberg 2013). They are not wellpositioned to carefully consider the negative consequences of their actions, whether for their victims or for themselves.

\section{Adolescence and the Juvenile Justice System}

The consequences of zero tolerance for anti-bullying policies are not limited to their inefficacy in reducing school bullying. They have actively contributed to its increased criminalization (American Psychological Association Zero Tolerance Taskforce 2006; Cascardi et al. 2014; Casella 2003). At least twelve state anti-bullying laws currently prescribe criminal sanctions for perpetrators, ranging from school suspension to incarceration (U.S. Department of Education 2011; www. cyberbullying.org). Adolescent bullies who are forcefully suspended from school are also more likely to become subsequently involved in the juvenile justice system (Fabelo et al. 2011; Gonsoulin et al. 2012; Wald and Losen 2003). Ironically, this may be especially true for adolescents with fewer behavioral problems prior to suspension (Monahan et al. 2014). Several states have made even clearer moves towards criminalization, by modifying existing criminal law, or creating new crimes specific to bullying (Cornell and Limber 2015). For example, in 2006 Idaho specified harassment, intimidation, or bullying among students as a crime under Chapter 9 Assault and Battery (I.C. §18-917A).
Nowhere is the mismatch between public policy and developmental science in regards to adolescence more evident than in the juvenile justice system. For many adolescents, age is the only factor keeping them from being tried in adult courts (Mears et al. 2014). As of 2014, 41 states use 17 years of age as the upper age of original jurisdiction, 8 states use 16 years, and 2 states (i.e., New York and North Carolina) use 15 as the cutoff (U.S. Department of Justice 2014). From a developmental perspective, these cut-offs are arbitrary. No scientific research indicates that 15,16 , or 17 -year olds differ substantially from one another in their social or cognitive abilities (Loeber and Farrington 2012; Scott and Steinberg 2008). Even within the juvenile courts, older adolescents are more likely to receive harsher punishments (e.g., time in a residential facility) (Brown and Sorensen 2014; Mears et al. 2014). This is despite a well-known, normative peak in delinquent behavior and risk-taking in middle-to-late adolescence, followed by a decrease as individuals enter adulthood (Moffitt 1993; Steinberg 2009).

The original purpose of the juvenile justice system was founded on the principle that children, by virtue of their immaturity, had more limited accountability and greater potential for rehabilitation compare with adults (Bernard and Kurlychek 2010). What we know about the developmental period of adolescence suggests that teens are both less culpable for poor decision making and more likely to demonstrate substantial improvements in their cognitive and social abilities with age (Cornell and Limber 2015). Moreover, it is well-documented argument that incarceration of adolescents is both more costly than prevention or treatment, and ultimately unsuccessful in reducing misbehavior (American Psychological Association Zero Tolerance Task Force 2006; Bear et al. 2000; Nance and Novy 2011).

Similar criticisms have been made against harsh sexting (i.e., exchanging sexually explicit images using electronic media) laws. Until recently, legal cases involving adolescent sexting have relied on child pornography laws. Federal statutory definitions criminalize sexually explicit conduct, including images, with an individual under 18 (U.S.C. $\$ 2256(2)(B)$ ) and consequences commonly include jail time or registration as a sex offender. The prevalence of sexting behavior is unclear, with studies ranging from $7 \%$ to as much as $32 \%$ of adolescents reporting participating in sexting as sender or receiver (Dake et al. 2012; Mitchell et al. 2012). Increasing recognition that the exchange of self-produced sexual images among teens is a distinct phenomenon has led many states to consider legislative reform, although the empirical research on sexting remain sparse. Sexting policies have been similarly plagued by ambiguously worded and overly broad definitions of the prohibited behaviors (Judge 2012; Sacco et al. 2010). 
However, progress has been made. Currently, twenty U.S. states have laws regarding sexting, and all twenty include provisions for when two minors are involved in sending or receiving explicit content (www.cyberbullying.org). As with bullying, adolescents' neurological immaturity may play an important role in their decision-making. Researchers find that adolescents' sexting is often impulsive and emotionally driven (Judge 2012; Sacco et al. 2010). Accordingly, some legislation limits the severity of punitive consequences for adolescents involved in sexting, although the prescribed punishments range from counseling or informal sanctions up to felony offense.

\section{Adolescence and Consequential Thinking}

Given the research on adolescent development, brain development, and anti-bullying programming and policies, it is not surprising that programming and policies are largely ineffective for older adolescents. State legislation has a long way to go in bringing anti-bullying policies and mandates closer in line with developmental science. Currently, the consequences for adolescents who bully are overly punitive during a developmental period when the social rewards associated with bullying have the greatest influence and adolescents are least capable of carefully considering the negative consequences of their actions. Confusing definitions and guidelines for meeting state mandates add to the difficulties schools face in implementing effective reforms. This is on top of growing evidence that zero tolerance policies relying on suspensions and expulsions simply do not reduce the occurrence of bullying and, in fact, often have negative consequences.

However, the past few years have seen greater empirical and public attention on the problem of bullying. The U.S. Department of Education, in 2010, published guidelines for eleven key components that should be included in antibullying laws to help ensure clear and comprehensive coverage (US Department of Education 2010; www.stop bullying.gov). Lawmakers and school officials are increasingly recognizing the value of adopting alternatives to zero tolerance in responding to student misbehavior more broadly. In 2015, the U.S. Departments of Education and Justice hosted a conference at the White House on "rethinking discipline," bringing school officials and law makers together to discuss strategies for creating positive school climates and alternatives to suspension. Empirical evidence grows supporting the value of adopting schoolwide prevention efforts, providing support for the mental health of both victims and perpetrators, and developing disciplinary strategies that are graduated to the nature and severity of individual cases of bullying (Hymel and
Swearer 2015; Morgan et al. 2014; Nickerson et al. 2013; Swearer et al. 2010). Given the power of legislation to effect change, continued attention and reform efforts hold promise for bridging the gap between developmental science and efforts to reduce bullying in schools.

\section{Social-Emotional Learning: Foundational Skills for Healthy Relationships}

An alternative to focusing on bullying, recent research has emphasized the role of positive behavioral interventions (http://www.pbis.org/school/bully-prevention) and socialemotional learning. Social and emotional learning involves the processes through which students and adults acquire and effectively apply the knowledge, attitudes, and skills necessary to understand and manage emotions, set and achieve positive goals, feel and show empathy for others, establish and maintain positive relationships, and make responsible decisions (Durlak et al. 2011). The Collaborative for Academic, Social, and Emotional Learning (CASEL) includes five core competencies for social-emotional learning: (1) Self-awareness-Recognizing one's emotions and values as well as one's strengths and limitations; (2) Self-management-Managing emotions and behaviors to achieve one's goals; (3) Social awarenessShowing understanding and empathy for others; (4) Relationship skills_-Forming positive relationships, working in teams, and dealing directly with conflict; and (5) Responsible decision making-Making ethical, constructive choices about personal and social behavior (Collaborative for Academic, Social, and Emotional Learning 2003). Participation in social-emotional learning programs was associated with positive impacts on six major student outcomes, including improved social skills, attitudes toward self and others, social behavior, and academic performance, as well as, reduced conduct problems and emotional distress. The impact on academic performance translated to an 11 percentile point gain in students' achievement test scores (Durlak et al. 2011). Students who receive social-emotional programming academically outperform their peers, get better grades, and graduate at higher rates (Bridgeland et al. 2013). Research has indicated that social-emotional learning programs with the best outcomes are multiyear in duration, use interactive, rather than purely knowledge-based instructional methods, and are integrated into the life of the school rather than being implemented as marginal add-ons (Zins et al. 2004). Despite the proven positive academic and social outcomes from SEL, there are fewer SEL programs for older adolescents. 


\section{The RULER Approach}

Researchers at the Yale Center for Emotional Intelligence have spent 15 years developing evidence-based approaches to teaching social and emotional learning across the developmental spectrum. RULER (www.ruler.yale.edu) is the Center's signature, whole-school approach to social-emotional learning that is grounded in both emotional intelligence (Mayer and Salovey 1997) and ecological systems theories (Bronfenbrenner 1979). It is built upon decades of research showing that the skills associated with recognizing, understanding, labeling, expressing, and regulating emotion (i.e., the RULER skills) are essential to effective leading, teaching, and learning, as well as other key outcomes, including sound decision making, quality relationships, mental and physical health and both academic and workplace performance (Brackett and Rivers 2013). Among adolescents, multiple studies have shown that teens with higher emotional intelligence have few attention problems, less anxiety and depression, better quality friendships, and academic performance (Rivers et al. 2012).

RULER begins with educating adult stakeholdersleaders, teachers, and support—so they can develop their own emotional intelligence skills, share a common language with students, and be the role models for applying emotional intelligence in everyday interactions. RULER training begins with four "anchor tools" which integrate emotional intelligence into everyday routines of the school and classroom learning environments. Ultimately, RULER is designed to embed emotional intelligence into the mission, vision, norms, policies, daily instruction and interactions with families and the community.

The four anchor tools are the Charter, Mood Meter, Meta-Moment and Blueprint. The Charter is developed collaboratively by faculty and staff (school charter) and across each grade level for students The Charter focuses on the feelings each stakeholder wants to have in their community, the identification of behaviors that foster those feelings, and guidelines for handling uncomfortable feelings and conflict. The Mood Meter is a tool to help all stakeholders identify feelings, build self- and socialawareness, set goals for how they want to feel, and develop emotion regulation strategizes to achieve daily goals. It's also used by educators to differentiate instruction. The Meta-Moment is a process to both improve reflective practices and develop the ability to manage difficult triggers. A key element of this tool is the cultivation of one's best self in order to be more preventative than reactive when dealing with triggers. The Blueprint is a problemsolving tool for complex interpersonal problems. It helps all stakeholders understand others' perspectives and to unpack the causes and consequences of difficult situations, including bullying.
Advanced training for middle school and high school students, includes the "Feeling Words Curriculum" for grades 6-8 and a series of courses for 9th to 12th grade students. The Feeling Words Curriculum training focuses on teaching educators how to embed an emotion vocabulary into existing lessons using a series of "steps," which include: personalized learning (e.g., storytelling around feelings), creative connections (e.g., visual and performing arts activities), home-school connections, character analysis, and cooperative learning (e.g., discovering effective emotion regulation strategies in small groups). See Brackett et al. (2012) for a more detailed overview of the Feeling Words Curriculum.

\section{Research on Social-Emotional Learning and RULER}

Accumulating evidence supports RULER's theory of change, including the positive effects of RULER on proximal and distal outcomes for educators and pre-school, elementary and middle school students. One quasi-experimental study tested the impact of RULER on 273 fifth and sixth grade students in 15 classrooms across three elementary schools (Brackett et al. 2012). Each school was assigned randomly to implement RULER in either fifth or sixth grade. Students were followed for one academic year with pre- and post-intervention data collection. Students in RULER classrooms relative to those in comparison classrooms had significantly greater gains in academic performance, specifically in English language arts and work habits/social development, compared to students in classrooms without RULER. The most rigorous study to date was a 2-year randomized controlled trial with 62 schools, including 155 classrooms, 105 teachers, and 3824 students (Rivers et al. 2013). Schools were assigned randomly to either integrate RULER into their fifth-and sixth-grade English language arts (ELA) classrooms or to serve as a comparison school, using their standard ELA curriculum. At the conclusion of the first year of implementation, classrooms in RULER schools were rated by independent observers as having more positive emotional climates (e.g., greater warmth and connectedness between teachers and students and higher regard for students' perspectives) compared to classrooms in "business-as-usual" schools (Rivers et al. 2013). Furthermore, results based on teacherreports showed more emotion-focused interactions between teachers and students and cooperative learning strategies in RULER classrooms. A follow-up study demonstrated that first-year shifts in classroom emotional climate were followed by improvements in classroom organization and instruction by the end of the second year (Hagelskamp et al. 2013). Compared to classrooms in the "business-asusual" schools, classrooms in RULER schools maintained 
more positive emotional climates and also showed impact on more distal outcomes, including better classroom organization and instructional support. Finally, it is expected that how RULER is implemented likely influences key outcomes. In one study examining the fidelity of RULER's implementation, students' higher emotional intelligence, more developed social problem-solving and conflict resolution skills were greater when their teachers had attended more trainings, taught more lessons, and were rated by naïve observers as high-quality implementers (Reyes et al. 2012).

\section{Social-Emotional Learning in Adolescence}

Integrating emotional intelligence training at the high school level has proven to be more challenging given the already overburdened schedules of many high school students and educators. Thus far, research across public, private, and boarding schools has demonstrated that a series of courses from 9th to 12th grade appears to be the most effective way to integrate RULER into high school settings. The courses included in RULER for high schools are highly experiential and ask students to consider three big questions: (1) Who am I? (2) What do I want out of high school career and beyond? (3) How am I going to get there? Throughout the courses, students build greater selfawareness through assessments of personality, mindset, and essential life skills such as emotional intelligence and creativity. They also build a vision for what they hope to achieve throughout their high school career. This vision is revisited periodically to ensure they are either on track or that they need change course based on a shift in their goals, values, or overarching vision. Students also identify strength and challenge areas, engage in self-reflective practices, and set goals for their physical and mental health, extracurricular activities, relationships, and academics. The larger goal of the course(s) is to apply all of this information to achieve their vision. As the high school RULER course is being developed, experiments to study outcomes and effectiveness are underway. Anecdotal feedback from high school educators and students has been very positive with many students indicating the value and importance of having time to reflect and develop skills they need to thrive in the "real world."

\section{Facebook and Social-Emotional Learning}

Given the complexities associated with the systemic integration of emotional intelligence into high school settings, the Yale Center for Emotional Intelligence in collaboration with Facebook developed a second, student-centered approach to social-emotional learning. InspirED (www. inspired.facebook.com) is a new resource center and online community that focuses on helping students and educators create more positive emotional climates in their schools. At the heart of inspirED is the creation of the "inspirED team" that is comprised of students and educators who work together to help create the best possible school climate. Teams work with school administrators to (1) conduct assessments that provide teams with immediate feedback on the emotional climate of the school, (2) unpack the findings of the assessment, (3) support the implementation of resources from the resource center that were (and will continue to be) developed by students in collaboration with social-emotional learning experts and high school educators, and (4) evaluate shifts in the emotional climate. The resources, which also are rooted in the latest research on social-emotional learning, positive youth development, and classroom climate, come in three formats: 10-min activities, 50-min classroom lessons, and project-based learning opportunities. The resource center also features video clips from related youth-serving organizations, and readings from scholarly and popular articles and websites. InspirED also provides opportunities for students, educators, and SEL experts around the globe to connect and share best practices, ask for advice, discuss challenges, and celebrate successes through two public Facebook groups, inspirED Educators (for adults) and inspirED Changemakers (for students).

\section{Conclusion}

After four decades of research and programming on bullying prevention and intervention (Hymel and Swearer 2015), will we really be able to end bullying and harassment? The answer has to be, "yes!" However, in order to end bullying and harassment, researchers, educators, parents, and students must team up with technology, business, communities, foundations, and stakeholders dedicated to creating a world where bullying and harassment do not exist. These efforts must be grounded in developmental science and implementation science if they are to be effective across primary, secondary, and collegiate settings. The inspirED mission serves to create lasting, positive behavioral change among adolescents and adults. Collectively, when we can change the narrative on bullying and harassment though education and social change, we can create a better world for everyone.

Acknowledgments The authors would like to thank the members of the Bullying Research Network (http://brnet.unl.edu) for providing a supportive network of researchers from whom we learn a great deal. We would also like to think Drs. Jennifer Green and Melissa Holt for their leadership on the special issue on adolescent bullying. We appreciate their guidance and patience as we worked on several iterations of this manuscript. Ultimately, translational research will be 
the key to ending bullying and providing evidence-based approaches to stopping these behaviors. This special issue makes an important contribution to our understanding of bullying behaviors during adolescence. SS would like to acknowledge Born This Way Foundation for their support of translational research and to the College of Education and Human Sciences for supporting the Bullying Research Network. MB would like to acknowledge Born This Way Foundation for their partnership in the Emotion Revolution, Jamie Lockwood from Facebook, and Robin Stern, Seth Wallace, and Nikki Elbertson at the Yale Center for Emotional Intelligence. RP would like to acknowledge Born This Way Foundation for their research support and to Dr. Susan Swearer for her guidance.

Authors' Contributions SS conceived of the idea for the manuscript and helped draft and edit the manuscript. MM drafted the manuscript content related to the limitations of current anti-bullying policy and legislation, and its inconsistencies with scientific knowledge of adolescent development. MB's contributions focused on a description of the Emotion Revolution research project and InspirED, an innovative, online resource center that was created to help schools integrate lessons social and emotional learning to build more positive school climates. RP provided a literature review on anti-bullying programs for adolescents and edited the manuscript. All authors read and approved the final manuscript.

Funding MB received funding from the Robert Wood Johnson Foundation for funding the Emotion Revolution Research. RP received funding from Born This Way Foundation. SS and MB did not have funding.

\section{Compliance with Ethical Standards}

Conflict of interest The authors report no conflict of interests.

Ethical Approval This manuscript was written in accordance with the APA 6th edition style manual. Since this is a review article, we did not need IRB approval.

Informed Consent Since this is a review article, we did not need informed consent.

\section{References}

Ali, R. (2010) U. S. Department of Education, Office for Civil Rights (2010). Dear colleague letter: Harassment and bullying. http:// www2.ed.gov/about/offices/list/ocr/letters/colleague-201010.pdf.

Alley, R., \& Limber, S. P. (2009). Legal issues for school personnel. In S. M. Swearer, D. L. Espelage, \& S. A. Napolitano (Eds.), Bullying prevention and intervention: Realistic strategies for schools (pp. 53-73). New York, NY: Guilford Press.

American Psychological Association Zero Tolerance Task Force. (2006). Are zero tolerance policies effective in the schools? An evidentiary review and recommendations. American Psychologist, 63, 852-862. doi:10.1037/0003-066X.63.9.852.

Aragon, S. R., Poteat, V. P., Espelage, D. L., \& Koeing, B. W. (2014). The influence of peer victimization on educational outcomes for LGBTQ and non-LGBTQ high school students. Journal of LGBT Youth, 11(1), 1-19. doi:10.1080/193653.2014.840761.

Bear, G. G., Webster-Stratton, C., Furlong, M. J., \& Rhee, S. (2000). Preventing aggression and violence. Preventing school problems-Promoting school success: Strategies and programs that work, 18, 140-157.
Beran, T. N., Rinaldi, C., Bickham, D. S., \& Rich, M. (2012). Evidence for the need to support adolescents dealing with harassment and cyber-harassment: Prevalence, progression, and impact. School Psychology International, 33, 562-576. doi:10. 1177/0143034312446976.

Bernard, T. J., \& Kurlychek, M. C. (2010). The cycle of juvenile justice. Oxford: Oxford University Press.

Blakemore, S. J., \& Mills, K. L. (2014). Is adolescence a sensitive period for sociocultural processing? Annual Review of Psychology, 65, 187-207. doi:10.1146/annurev-psych-010213-115202.

Borgwald, K., \& Theixos, H. (2013). Bullying the bully: Why zerotolerance policies get a failing grade. Social Influence, 8, 149-160. doi:10.1080/15534510.2012.724030.

Boyd, D. (2014). It's complicated: The social lives of networked teens. New Haven, Connecticut: Yale University Press.

Brackett, M. A, Caruso, D. R, Stern, R. (2006-2015). Anchors of emotional intelligence. New Haven, CT: Emotionally Intelligent Schools, LLC.

Brackett, M. A., \& Rivers, S. E. (2013). Transforming students' lives with social and emotional learning. In R. Pekrun \& L. Linnenbrink-Garcia (Eds.), International handbook of emotions in education (pp. 368-388). New York, NY: Routledge/Taylor and Francis Group.

Brackett, M. A., Rivers, S. E., Reyes, M. R., \& Salovey, P. (2012). Enhancing academic performance and social and emotional competence with the RULER feeling words curriculum. Learning and Individual Differences, 22, 218-224. doi:10.1016/j. lindif.2010.10.002.

Bridgeland, J., Bruce, M., Hariharan, A. (2013). The missing piece: A national teacher survey on how social and emotional learning can empower children and transform schools. https://casel. squarespace.com/library/the-missing-piece.

Bronfenbrenner, U. (1979). The ecology of human development: Experiments by nature and design. Cambridge, MA: Harvard University Press.

Brown, J. M., \& Sorensen, J. R. (2014). Legal and extra-legal factors related to the imposition of blended sentences. Criminal Justice Policy Review, 25, 227-241. doi:10.1177/0887403412465431.

Cascardi, M., Brown, C., Iannarone, M., \& Cardona, N. (2014). The problem with overly broad definitions of bullying: Implications for the schoolhouse, the statehouse, and the ivory tower. Journal of School Violence, 13, 253-276. doi:10.1080/15388220.2013. 846861.

Casella, R. (2003). Zero tolerance policy in schools: Rationale, consequences, and alternatives. Teachers College Record, 105, 872-892. doi:10.1111/1467-9620.00271.

Chesir-Teran, D. (2003). Conceptualizing and addressing heterosexism in high schools: A setting-level approach. American Journal of Community Psychology, 31, 269-279. doi:10.1023/a: 1023910820994.

Chesir-Teran, D., \& Hughes, D. (2009). Heterosexism in high school and victimization among lesbian, gay, bisexual, and questioning students. Journal of Youth Adolescence, 38, 963-975. doi:10. 1007/s10964-008-9364-x.

Cohen, A. O., \& Casey, B. J. (2014). Rewiring juvenile justice: The intersection of developmental neuroscience and legal policy. Trends in Cognitive Sciences, 18, 63-65. doi:10.1016/j.tics.2013. 11.002 .

Collaborative for Academic, Social, and Emotional Learning. (2003). Safe and sound: An educational leader's guide to evidencebased social and emotional learning programs. https://casel. squarespace.com/s/safe-and-sound-il-edition.pdf.

Cornell, D., \& Huang, F. (2014). School counselor use of peer nominations to identify victims of bullying. Professional School Counseling, 18(1), 191-205. doi:10.5330/2156-759x-18.1.191. 
Cornell, D., \& Limber, S. P. (2015). Law and policy on the concept of bullying at school. American Psychologist, 70, 333-343. doi:10. 1037/a0038558.

Council on School Health. (2013). Out-of-school suspension and expulsion. Pediatrics, 131(3), e1000-e1007. doi:10.1542/peds. 2012-3932.

Crone, E. A., \& Dahl, R. E. (2012). Understanding adolescence as a period of social-affective engagement and goal flexibility. Nature Reviews Neuroscience, 13, 636-650. doi:10.1038/ nrn3313.

Dake, J. A., Price, J. H., Maziarz, L., \& Ward, B. (2012). Prevalence and correlates of sexting behavior in adolescents. American Journal of Sexuality Education, 7, 1-15. doi:10.1080/15546128. 2012.650959.

Davis V. Monroe County Board of Education, 526 U.S. 629 (1999).

Dresler-Hawke, E., \& Whitehead, D. (2009). The behavioral ecological model as a framework for school-based anti-bullying health promotion interventions. The Journal of School Nursing, 25, 195-204. doi:10.1177/1059840509334364.

Durlak, J. A., Weissberg, R. P., Dymnicki, A. B., Taylor, R. D., \& Schellinger, K. B. (2011). The impact of enhancing students' social and emotional learning: A meta-analysis of school-based universal interventions. Child Development, 82, 405-432.

Ellis, B. J., Volk, A. A., Gonzalez, J., \& Embry, D. D. (2015). The meaningful roles intervention: An evolutionary approach to reducing bullying and increasing prosocial behavior. Journal of Research on Adolescence, . doi:10.1111/jora.12243.

Espelage, D. L., Aragon, S. R., Birkett, M., \& Koenig, B. W. (2008). Homophobic teasing, psychological outcomes, and sexual orientation among high school students: What influence do parents and schools have? [Special issue]. School Psychology Review, 37, 202-216.

Fabelo, T., Thompson, M. D., Plotkin, M., Carmichael, D., Marchbanks, M. P., \& Booth, E. A. (2011). Breaking schools' rules: A statewide study of how school discipline relates to students' success and juvenile justice involvement. New York, NY: Council of State Governments Justice Center.

Ferguson, C. J., Miguel, C. S., Kilburn, J. C., \& Sanchez, P. (2007). The effectiveness of school-based anti-bullying programs: A meta-analytic review. Criminal Justice Review, 32, 401-414. doi:10.1177/0734016807311712.

Garandeau, C. F., Lee, I. A., \& Salmivalli, C. (2014). Differential effects of the KiVa anti-bullying program on popular and unpopular bullies. Journal of Applied Developmental Psychology, 35(1), 44-50. doi:10.1016/j.appdev.2013.10.004.

Gardner, M., \& Steinberg, L. (2005). Peer influence on risk taking, risk preference, and risky decision making in adolescence and adulthood: An experimental study. Developmental Psychology, 41, 625-635. doi:10.1037/0012-1649.41.4.625.

Gina, G., \& Pozzoli, T. (2009). Association between bullying and psychosomatic problems: A meta-analysis. Pediatrics, 123, 1059-1065. doi:10.1542/peds.2008-1215.

Gladden, R. M., Vivolo-Kantor, A. M., Hamburger, M. E., \& Lumpkin, C. D. (2014). Bullying surveillance among youths: Uniform definitions for public health and recommended data elements. Atlanta, GA: National Center for Injury Prevention and Control, Centers for Disease Control and Prevention and U.S. Department of Education.

Glew, G. M., Fan, M. Y., Katon, W., \& Rivara, F. P. (2008). Bullying and school safety. Journal of Pediatrics, 152, 123-128. doi:10. 1016/j.jpeds.2007.05.045.

Gonsoulin, S., Zablocki, M., \& Leone, P. E. (2012). Safe schools, staff development, and the school-to-prison pipeline. Teacher Education and Special Education: The Journal of the Teacher Education Division of the Council for Exceptional Children, 35, 309-319. doi:10.1177/0888406412453470.
Graff, C., Stufft, D. (2011). Increasing visibility for LGBTQ students: What schools can do to create inclusive classroom communities. Current Issues in Education, 14(1). http://cie.asu.edu/ojs/index. $\mathrm{php} /$ cieatasu/article/view/636.

Hagelskamp, C., Brackett, M. A., Rivers, S. E., \& Salovey, P. (2013). Improving classroom quality with the RULER approach to social and emotional learning: Proximal and distal outcomes. American Journal of Community Psychology, 51, 530-543. doi:10.1007/ s10464-013-9570-x.

Hall, W. J., \& Chapman, M. V. (2016). The role of school context in implementing statewide anti-bullying policy and protecting students. Educational Policy. doi:10.1177/0895904816637689.

Hatzenbuehler, M. L., Schwab-Reese, L., Ranapurwala, S. I., Hertz, M. F., \& Ramirez, M. R. (2015). Associations between antibullying policies and bullying in 25 states. JAMA Pediatrics, 169, e152411. doi:10.1001/jamapediatrics.2015.2411.

Hawley, P. H., Stump, K. N., \& Ratliff, J. (2011). Sidestepping the jingle fallacy. In D. L. Espelage \& S. M. Swearer (Eds.), Bullying in North American schools (2nd ed., pp. 101-116). New York, NY: Routledge.

Holben, D. M., \& Zirkel, P. A. (2014). School bullying litigation: An empirical analysis of the case law. Akron Law Review, 47, 299-328.

Holt, M. K., Vivolo-Kantor, A. M., Polanin, J. R., Holland, K. M., DeGue, S., Matjasko, J. L., et al. (2015). Bullying and suicide ideation and behaviors: A meta-analysis. Pediatrics, 135, 496-509. doi:10.1542/peds.2014-1864.

Hymel, S., McClure, R., Miller, M., Shumka, E., \& Trach, J. (2015). Addressing school bullying: Insights from theories of group processes. Journal of Applied Developmental Psychology, 37, 16-24. doi:10.1016/j.appdev.2014.11.008.

Hymel, S., \& Swearer, S. M. (2015). Four decades of research on school bullying: An introduction. American Psychologist, 70, 293-299. doi:10.1037/a0038928.

Jones, R. M., Somerville, L. H., Li, J., Ruberry, E. J., Powers, A., Mehta, N., et al. (2014). Adolescent-specific patterns of behavior and neural activity during social reinforcement learning. Cognitive, Affective, \& Behavioral Neuroscience, 14, 683-697. doi:10.3758/s13415-014-0257-z.

Judge, A. M. (2012). "Sexting" among U.S. adolescents: Psychological and legal perspectives. Harvard Review of Psychiatry, 20, 86-96. doi:10.3109/10673229.2012.677360.

Keipi, T., \& Oksanen, A. (2014). Self-exploration, anonymity and risks in the online setting: Analysis of narratives by 14-18-year olds. Journal of Youth Studies, 17, 1097-1113. doi:10.1080/ 13676261.2014.881988.

Kull, R. M., Kosciw, J. G., \& Greytak, E. A. (2015). From statehouse to schoolhouse: Anti-bullying policy efforts in U.S. States and school districts. New York: GLSEN.

L. W. v. Toms River Regional Schools Board of Education, 189 N.J. 381 (N.J. 2007).

Leff, S. S., Power, T. J., \& Goldstein, A. B. (2004). Outcome measures to assess the effectiveness of bullying-prevention programs in the schools. In D. L. Espelage \& S. M. Swearer (Eds.), Bullying in American schools: A social-ecological perspective on prevention and intervention ( $\mathrm{pp}$. 269-293). Mahwah, NJ, US: Lawrence Erlbaum Associates Publishers.

Limber, S. P. (2010). Implementation of the Olweus Bullying Prevention Program: Lessons learned from the field. In D. Espelage \& S. Swearer (Eds.), Bullying in North American schools: A social-ecological perspective on prevention and intervention (2nd ed., pp. 291-306). New York, NY: Routledge.

Loeber, R., \& Farrington, D. P. (2012). From juvenile delinquency to adult crime: Criminal careers, justice policy and prevention. Oxford: Oxford University Press.

Luna, B., Garver, K. E., Urban, T. A., Lazar, N. A., \& Sweeney, J. A. (2004). Maturation of cognitive processes from late childhood to 
adulthood. Child Development, 75, 1357-1372. doi:10.1111/j. 1467-8624.2004.00745.x.

Mayer, J. D., \& Salovey, P. (1997). What is emotional intelligence? In P. Salovey \& D. J. Sluyter (Eds.), Emotional development and emotional intelligence: Educational implications (pp. 3-34). New York, NY: Basic Books Inc.

McDougall, P., \& Vaillancourt, T. (2015). Long-term adult outcomes of peer victimization in childhood and adolescence: Pathways to adjustment and maladjustment. American Psychologist, 70, 300-310. doi:10.1037/app39174.

Mears, D. P., Cochran, J. C., Stults, B. J., Greenman, S. J., Bhati, A. S., \& Greenwald, M. A. (2014). The "true" juvenile offender: Age effects and juvenile court sanctioning. Criminology, 52, 169-194. doi:10.1111/1745-9125.12034.

Merrell, K. W., Gueldner, B. A., Ross, S. W., \& Isava, D. M. (2008). How effective are school bullying intervention programs? A meta-analysis of intervention research. School Psychology Quarterly, 23, 26-42. doi:10.1037/1045-3830.23.1.26.

Mills, K. L., Goddings, A. L., Clasen, L. S., Giedd, J. N., \& Blakemore, S. J. (2014). The developmental mismatch in structural brain maturation during adolescence. Developmental Neuroscience, 36, 147-160. doi:10.1159/000362328.

Milner, M. (2004). Freaks, geeks, and cool kids: American teenagers, schools, and the culture of consumption. New York: Routledge.

Mitchell, K. J., Finkelhor, D., Jones, L. M., \& Wolak, J. (2012). Prevalence and characteristics of youth sexting: A national study. Pediatrics, 129, 13-20. doi:10.1542/peds.2011-1730.

Moffitt, T. E. (1993). Adolescence-limited and life-course-persistent antisocial behavior: A developmental taxonomy. Psychological Review, 100, 674-701. doi:10.1037/0033-295x.100.4.674.

Monahan, K. C., VanDerhei, S., Bechtold, J., \& Cauffman, E. (2014). From the school yard to the squad car: School discipline, truancy, and arrest. Journal of Youth and Adolescence, 43, 1110-1122. doi:10.1007/s10964-014-0103-1.

Morgan, E., Salomon, N., Plotkin, M., \& Cohen, R. (2014). The school discipline consensus report: Strategies from the field to keep students engaged in school and out of the juvenile justice system. New York, NY: The Council of State Governments Justice Center. http://csgjusticecenter.org/wp-content/uploads/ 2014/06/The_School_Discipline_Consensus_Report.pdf.

Nance, D., \& Novy, F. A. (2011). The power of education in juvenile justice. In A. R. Roberts \& D. W. Springer (Eds.), Juvenile delinquency and juvenile justice: Policies, programs and intervention strategies. Sudbury: Jones and Bartlett Publishers.

Nelson, E., McClure, E., Monk, C., Zarahn, E., Leibenluft, E., Pine, D., et al. (2003). Developmental differences in neuronal engagement during implicit encoding of emotional faces: An event-related fMRI study. Journal of Child Psychology, Psychiatry and Allied Disciplines, 44, 1015-1024. doi:10.1111/14697610.00186.

Nickerson, A. B., Cornell, D. G., Smith, J. D., \& Furlong, M. J. (2013). School antibullying efforts: Advice for education policymakers. Journal of School Violence, 12, 268-282. doi:10.1080/15388220.2013.787366.

O'Connell, P., Pepler, D., \& Craig, W. (1999). Peer involvement in bullying: Insights and challenges for intervention. Journal of Adolescence, 22, 437-452. doi:10.1006/jado.1999.0238.

Olweus, D. (2013). School bullying: Development and some important challenges. Annual Review of Clinical Psychology, 9, 751-780. doi:10.1146/annurev-clinpsy-050212-185516.

Pepler, D. J., Craig, W. M., Connolly, J. A., Yulie, A., McMaster, L., \& Jiang, D. (2006). A developmental perspective on bullying. Aggressive Behavior, 32(4), 376-384. doi:10.1002/ab.20136.

Polanin, J. R., Espelage, D. L., \& Pigott, T. D. (2012). A metaanalysis of school-based bullying prevention programs' effect on bystander intervention behavior. School Psychology Review, 41(1), 47-65.

Policies \& laws. (2015). http://www.stopbullying.gov/laws/index. html.

Poteat, V. P. (2008). Contextual and moderating effects of the peer group climate on use of homophobic epithets [Special issue]. School Psychology Review, 37, 188-201.

Poteat, V. P., Aragon, S. R., Espelage, D. L., \& Koenig, B. W. (2009). Psychosocial concerns of sexual minority youth: Complexity and caution in group differences. Journal of Consulting and Clinical Psychology. doi:10.1037/a0014158.

Radliff, K. M., Wheaton, J. E., Robinson, K., \& Morris, J. (2012). Illuminating the relationship between bullying and substance use among middle and high school youth. Addictive Behaviors, 37, 569-572. doi:10.1016/j.addbeh.2012.01.001.

Reijntjes, A., Vermande, M., Olthof, T., Goossens, F. A., Van De Schoot, R., Aleva, L., et al. (2013). Costs and benefits of bullying in the context of the peer group: A three wave longitudinal analysis. Journal of Abnormal Child Psychology, 41, 1217-1229. doi:10.1007/s10802-013-9759-3.

Reyes, M. R., Brackett, M. A., Rivers, S. E., Elbertson, N. A., \& Salovey, P. (2012). The interaction effects of program training, dosage, and implementation quality on targeted student outcomes for the RULER approach to social and emotional learning. School Psychology Review, 41, 82-99.

Rivers, S. E., Brackett, M. A., Reyes, M. R., Elbertson, N. A., \& Salovey, P. (2013). Improving the social and emotional climate of classrooms: A Clustered randomized controlled trial testing the RULER Approach. Prevention Science, 14, 77-87. doi:10. 1007/s11121-012-0305-2.

Rivers, S. E., Brackett, M. A., Reyes, M. R., Mayer, J. D., Caruso, D. R., \& Salovey, P. (2012). Measuring emotional intelligence in early adolescence with the MSCEITYV psychometric properties and relationship with academic performance and psychosocial functioning. Journal of Psychoeducational Assessment, 30, 344-366. doi:10.1177/0734282912449443.

Rivers, I., \& Noret, N. (2008). Well-being among same-sex- and opposite-sex attracted youth at school [Special issue]. School Psychology Review, 37, 174-187.

Robers, S., Zhang, A., Morgan, R.E., \& Musu-Gillette, L. (2015). Indicators of school crime and safety: 2014 (NCES 2015-072/ NCJ 248036). Washington, DC: National Center for Education Statistics, U.S. Department of Education, and Bureau of Justice Statistics, Office of Justice Programs, U.S. Department of Justice. http://nces.ed.gov/pubsearch/pubinfo.asp?pubid= 2015072.

Rodkin, P. C., Espelage, D. L., \& Hanish, L. D. (2015). A relational framework for understanding bullying: Developmental antecedents and outcomes. American Psychologist, 70, 311-321. doi:10.1037/a0038658.

Rose, C. A., Swearer, S. M., \& Espelage, D. L. (2012). Bullying and students with disabilities: The untold narrative. Focus on Exceptional Children, 45, 1-10.

Roth, G., Kanat-Maymon, Y., \& Bibi, U. (2011). Prevention of school bullying: The important role of autonomy-supportive teaching and internalization of pro-social values. British Journal of Educational Psychology, 81, 654-666. doi:10.1348/2044-8279. 002003.

Ryan, W., \& Smith, D. J. (2009). Antibullying programs in schools: How effective are evaluation practices? Prevention Science, 10, 248-262. doi:10.1007/s11121-009-0128-y.

Sacco, D., Argudin, R., Maguire, J., \& Tallon, K. (2010). Sexting: Youth practices and legal implications. Cambridge, MA: Youth and Media Policy Working Group Initiative, Berkman Center for Internet \& Society, Harvard University. 
Sacco, D., Silbaugh, K. B., Corredor, F., Casey, J., \& Doherty, D. (2012). An overview of state anti-bullying legislation and other related laws (pp. 2013-2014). Cambridge, MA: Berkman Center Research Publication, Report no.

Sacks, J., \& Salem, R. S. (2009). Victims without legal remedies: Why kids need schools to develop comprehensive anti-bullying policies. Albany Law Review, 72, 147-190.

Salmivalli, C. (2010). Bullying and the peer group: A review. Aggression and Violent Behavior, 15, 112-120. doi:10.1016/j. avb.2009.08.007.

Scott, E. S., \& Steinberg, L. (2008). Adolescent development and the regulation of youth crime. The Future of Children, 18, 15-33. doi:10.1353/foc. 0.0011 .

Scruggs v. Meriden Board of Education, 2005 WL 2072312 (D. Conn Aug. 26, 2005).

Skiba, R. J., \& Knesting, K. (2001). Zero tolerance, zero evidence: An analysis of school disciplinary practice. New Directions for Youth Development, 92, 17-43. doi:10.1002/yd.23320019204.

Smith, A. R., Chein, J., \& Steinberg, L. (2014). Peers increase adolescent risk taking even when the probabilities of negative outcomes are known. Developmental Psychology, 50, $1564-1568$.

Smith, A. R., Steinberg, L., Strang, N., \& Chein, J. (2015). Age differences in the impact of peers on adolescents' and adults' neural response to reward. Developmental Cognitive Neuroscience, 11, 75-82. doi:10.1016/j.den.2014.08.010.

Somerville, L. H. (2013). The teenage brain sensitivity to social evaluation. Current Directions in Psychological Science, 22, 121-127. doi:10.1177/0963721413476512.

Somerville, L. H., \& Casey, B. J. (2010). Developmental neurobiology of cognitive control and motivational systems. Current Opinion in Neurobiology, 20, 236-241. doi:10.1016/j.conb.2010. 01.006.

Steinberg, L. (2008). A social neuroscience perspective on adolescent risk-taking. Developmental Review, 28, 78-106. doi:10.1016/j. dr.2007.08.002.

Steinberg, L. (2009). Adolescent development and juvenile justice. Annual Review of Clinical Psychology, 5, 459-485. doi:10.1146/ annurev.clinpsy.032408.153603.

Steinberg, L. (2010). A dual systems model of adolescent risk-taking. Developmental Psychobiology, 52, 216-224. doi:10.1002/dev. 20445.

Steinberg, L. (2013). Does recent research on adolescent brain development inform the mature minor doctrine? Journal of Medicine and Philosophy, 38, 268-282.

Steinberg, L., Graham, S., O’Brien, L., Woolard, J., Cauffman, E., \& Banich, M. (2009). Age differences in future orientation and delay discounting. Child Development, 80, 28-44. doi:10.1111/j. 1467-8624.2008.01244.x.

Swearer, S. M., Espelage, D. L., \& Napolitano, S. A. (2009). Bullying prevention and intervention: Realistic strategies for schools. New York: Guilford.

Swearer, S. M., Espelage, D. L., Vaillancourt, T., \& Hymel, S. (2010). What can be done about school bullying? Linking research to educational practice. Educational Researcher, 39(1), 38-47. doi:10.3102/0013/0013189X09357622.
Swearer, S. M., Turner, R. K., Givens, J. E., \& Pollack, W. S. (2008). "You're So Gay!" Do difference forms of bullying matter for adolescent males? School Psychology Review, 37, 160-173.

Ttofi, M. M., \& Farrington, D. P. (2009). What works in preventing bullying: Effective elements of anti-bullying programmes. Journal of Aggression, Conflict And Peace Research, 1(1), 13-24. doi:10.1108/17596599200900003.

Ttofi, M. M., \& Farrington, D. P. (2011). Effectiveness of schoolbased programs to reduce bullying: A systematic and metaanalytic review. Journal of Experimental Criminology, 7(1), 27-56. doi:10.1007/s11292-010-9109-1.

U.S. Department of Education, Office for Civil Rights. (2010). Dear colleague letter: Harassment and bullying. http://www2.ed.gov/ about/offices/list/ocr/letters/colleague-201010.pdf.

U.S. Department of Education, Office for Civil Rights. (2014). Dear colleague letter: Responding to bullying of students with disabilities. http://www2.ed.gov/about/offices/list/ocr/letters/col leaguebullying-201410.pdf.

U.S. Department of Education Office of Planning, Evaluation and Policy Development, Policy and Program Studies Service (USDOE). (2011). Analysis of state bullying laws and policies. Washington, DC: Author.

U.S. Department of Education, Office of Special Education and Rehabilitative Services (2013). Dear colleague letter: Bullying of students with disabilities. https://www2.ed.gov/policy/speced/ guid/idea/memosdcltrs/bullyingdcl-8-20-13.pdf.

U.S. Department of Justice, Office of Juvenile Justice and Delinquency Prevention (2014). Statistical Briefing Book. http://www. ojjdp.gov/ojstatbb/structure_process/qa04101.asp.

Volk, A. A., Dane, A. V., \& Marini, Z. A. (2014). What is bullying? A theoretical redefinition. Developmental Review, 34, 327-343. doi:10.1016/j.dr.2014.09.001.

Wald, J., \& Losen, D. J. (2003). Defining and redirecting a school-toprison pipeline. New Directions for Youth Development, 99, 9-15. doi:10.1002/yd.51.

Weaver, L. M., Brown, J. R., Weddle, D. B., \& Aalsma, M. C. (2013). A content analysis of protective factors within states' antibullying laws. Journal of School Violence, 12, 156-173. doi:10. 1080/15388220.2012.751537.

Yeager, D. S., Fong, C. J., Lee, H. Y., \& Espelage, D. L. (2015). Declines in efficacy of anti- bullying programs among older adolescents: Theory and a three-level meta-analysis. Journal of Applied Developmental Psychology, 37, 36-51. doi:10.1016/j. appdev.2014.11.005.

Zins, J. E., Bloodworth, M. R., Weissberg, R. P., \& Walberg, H. J. (2004). The scientific base linking social and emotional learning to school success. In J. Zins, R. Weissberg, M. Wang, \& H. J. Walberg (Eds.), Building academic success on social and emotional learning: What does the research say? (pp. 3-22). New York: Teachers College Press. 